\title{
The Effects of Zinc and Other Divalent Cations on M-Current in Ventral Tegmental Area Dopamine Neurons
}

\author{
Susumu Koyama ${ }^{1,2 *}$, Munechika Enjoji², Mark S. Brodie ${ }^{1}$, Sarah B. Appel1 \\ ${ }^{1}$ Department of Physiology and Biophysics, University of Illinois at Chicago, College of Medicine, \\ Chicago, USA \\ ${ }^{2}$ Department of Clinical Pharmacology, Faculty of Pharmaceutical Sciences, Fukuoka University, Fukuoka, Japan \\ Email: susumuk@fukuoka-u.ac.jp
}

Received 4 October 2014; revised 22 November 2014; accepted 5 December 2014

Copyright (C) 2014 by authors and Scientific Research Publishing Inc.

This work is licensed under the Creative Commons Attribution International License (CC BY). http://creativecommons.org/licenses/by/4.0/

(c) (i) Open Access

\begin{abstract}
Ventral tegmental area dopamine (DA VTA) neurons are important for the reinforcing effects of drugs of abuse such as ethanol and nicotine. We have previously shown that M-current $\left(I_{M}\right)$ regulates the excitability of DA VTA neurons. Zinc $\left(\mathrm{Zn}^{2+}\right)$ contributes to the regulation of neuronal excitation as a neuromodulator. In the present study, we investigated zinc effect on the properties of $I_{M}$ and the spontaneous firing frequency of DA VTA neurons. The standard deactivation protocol was used to measure $I_{M}$ during voltage-clamp recording with a hyperpolarizing voltage step to $\mathbf{- 4 0}$ $\mathrm{mV}$ from a holding potential $\left(V_{H}\right)$ of $-25 \mathrm{mV}$. $\mathrm{Zn}^{2+}(100 \mu \mathrm{M})$ inhibited $I_{M}$ amplitude and $I_{M}$ recovered completely from the inhibition after the washout of $\mathrm{Zn}^{2+}$. $\mathrm{Zn}^{2+}$ inhibited $\mathrm{I}_{\mathrm{M}}$ in a concentrationdependent manner $\left(\mathrm{IC}_{50}\right.$ : $5.8 \mu \mathrm{M}$ ). When hyperpolarizing voltage steps were given to $-65 \mathrm{mV}$ (in $10 \mathrm{mV}$ increments) from a $V_{\mathrm{H}}$ of $-25 \mathrm{mV}, \mathrm{Zn}^{2+}(100 \mu \mathrm{M})$ reduced $I_{M}$ amplitude at each voltage and zinc inhibition of $I_{M}$ was not voltage-dependent. $\mathrm{Zn}^{2+}$ increased the spontaneous firing frequency of DA VTA neurons in a concentration-dependent manner, suggesting that $\mathrm{Zn}^{2+}$ causes excitation of DA VTA neurons through an action on $I_{M}$. $I_{M}$ of DA VTA neurons was inhibited by $100 \mu M$ divalent cations in increasing order of potency: $\mathrm{Ba}^{2+}(16 \%)<\mathrm{Co}^{2+}(25 \%)<\mathrm{Ni}^{2+}(40 \%)<\mathrm{Cd}^{2+}(59 \%)<\mathrm{Zn}^{2+}$ $(67 \%)$. These results suggest that $\mathrm{Zn}^{2+}$ may exert physiologically significant regulation of neuronal excitability in DA VTA neurons.
\end{abstract}

\section{Keywords}

Divalent Cation, Dopaminergic, Nystatin-Perforated Patch Recording, Zinc

"Corresponding author.

How to cite this paper: Koyama, S., Enjoji, M., Brodie, M.S. and Appel, S.B. (2014) The Effects of Zinc and Other Divalent Cations on M-Current in Ventral Tegmental Area Dopamine Neurons. J. Biomedical Science and Engineering, 7, $1075-1087$. 


\section{Introduction}

The ventral tegmental area dopamine (DA VTA) neurons send axons which synapse in the nucleus accumbens (NAcb) [1] and the excitation of DA VTA neurons results in increased dopamine release in the NAcb [2]-[4], which is important for the reinforcing effects of drugs of abuse [5] [6]. M-current $\left(\mathrm{I}_{\mathrm{M}}\right)$ is a voltage-dependent $\mathrm{K}^{+}$ current which is activated at the subthreshold range of membrane potential and contributes to the regulation of repetitive firing [7] [8]. $\mathrm{I}_{\mathrm{M}}$ is mediated by current through KCNQ type potassium channels [9]. Among the five types of channel subunits (KCNQ1 to 5) [10], immunohistochemical studies have shown that the KCNQ2 and KCNQ4 channel proteins are present in VTA neurons [11] [12]. DA VTA neurons have intrinsic pacemaker activity and a recent study has reported that the KCNQ4 channel subunit is the major component of $\mathrm{I}_{M}$ in DA VTA neurons and critical for the excitability of these neurons [13]. Thus, KCNQ channels ( $\mathrm{I}_{\mathrm{M}}$ ) of DA VTA neurons may be a critical factor in the mediation of the reinforcing effect of drugs of abuse.

Zinc $\left(\mathrm{Zn}^{2+}\right)$ is present in the midbrain in higher concentrations than in the blood and the total amount of $\mathrm{Zn}^{2+}$ is estimated to be $4225 \mathrm{ng}$ in the substantia nigra (SN) in human brain [14]. The majority of $\mathrm{Zn}^{2+}$ is associated with a $\mathrm{Zn}^{2+}$-containing enzyme in cytoplasm [15] and the remainder of $\mathrm{Zn}^{2+}$ is present in presynaptic vesicles [16]. $\mathrm{Zn}^{2+}$ is thought to be co-released with neurotransmitter from presynaptic nerve terminals [17] and to act postsynaptically by the regulation of ligand-gated ion channels and voltage-dependent ion channels [18]. Extracellular $\mathrm{Zn}^{2+}$ inhibits $\mathrm{I}_{\mathrm{M}}$; the $\mathrm{IC}_{50}$ values are $11 \mu \mathrm{M}$ in rodent neuroblastoma $\mathrm{x}$ glioma hybrid cells [19] and $300 \mu \mathrm{M}$ in bullfrog sympathetic neurons [20]. It has been reported that $\mathrm{Zn}^{2+}(10-100 \mu \mathrm{M})$ accelerates evoked action potential generation, suggesting that it increases excitability of midbrain DA neurons of the SN in a concentration-dependent manner [21]. We have previously shown that $\mathrm{I}_{\mathrm{M}}$ underlies the fast and slow component of the action potential after hyperpolarization without affecting the middle component and prolongs the inter-spike interval to decrease the excitability of DA VTA neurons [22]. Therefore, it is hypothesized that relatively low concentrations of $\mathrm{Zn}^{2+}$ may inhibit $\mathrm{I}_{\mathrm{M}}$ and increase the excitability of DA VTA neurons. This hypothesis was tested in the present study, investigating whether $\mathrm{Zn}^{2+}$ would modulate the properties of $\mathrm{I}_{\mathrm{M}}$ and the excitability of DA VTA neurons through an action on $\mathrm{I}_{\mathrm{M}}$. In addition, we examined the potency of other divalent cations, barium $\left(\mathrm{Ba}^{2+}\right)$, cadmium $\left(\mathrm{Cd}^{2+}\right)$, cobalt $\left(\mathrm{Co}^{2+}\right)$ and nickel $\left(\mathrm{Ni}^{2+}\right)$ on $\mathrm{I}_{\mathrm{M}}$ in DA VTA neurons.

\section{Materials and Methods}

\subsection{Preparation of Dissociated Neurons}

Animals used in this study were treated in strict accordance with the American Physiological Society’s Guiding Principles in the Care and Use of Animals and the US National Institutes for Health Guide for the Care and Use of Laboratory Animals; the protocol for all experimental methods was approved by the Institutional Animal Care Committee of the University of Illinois at Chicago. Both male and female Fisher 344 rats (14 - 18 days old) were decapitated and the brain quickly removed. The brain was placed in an ice-cold cutting solution (in mM: 220 sucrose, $2.5 \mathrm{KCl}, 2.4 \mathrm{CaCl}_{2}, 1.3 \mathrm{MgSO}_{4}, 1.24 \mathrm{NaH}_{2} \mathrm{PO}_{4}, 26 \mathrm{NaHCO}_{3}, 11$-glucose), which was constantly bubbled with 95\% $\mathrm{O}_{2}$ and 5\% $\mathrm{CO}_{2}$. Transverse brain slices (350 - $400 \mu \mathrm{m}$ thick) were made on a Vibratome (Series 1000 plus, St. Louis, MO, USA). The brain slices were incubated for 3 - $4 \mathrm{hr}$ in an artificial cerebrospinal fluid (ACSF) (in mM: $126 \mathrm{NaCl}, 2.5 \mathrm{KCl}, 2.4 \mathrm{CaCl}_{2}, 1.3 \mathrm{MgSO}_{4}, 1.24 \mathrm{NaH}_{2} \mathrm{PO}_{4}, 26 \mathrm{NaHCO}_{3}, 11$-glucose, osmolarity $300 \mathrm{mOsm}$ ), which was constantly bubbled with $95 \% \mathrm{O}_{2}$ and $5 \% \mathrm{CO}_{2}$ at $26^{\circ} \mathrm{C}$. VTA neurons were dissociated as previously described [22]. Specifically, brain slices were next incubated in a HEPES-buffered solution (see below) containing papain $(15-18 \mathrm{U} / \mathrm{ml})$ at $32^{\circ} \mathrm{C}$ for $20-25 \mathrm{~min}$. After papain treatment, the brain slices were further incubated in the ACSF for 20 - $40 \mathrm{~min}$. The VTA neurons were dissociated by a vibrating stylus apparatus for dispersing cells from the brain slices. First the brain slice was transferred to a poly- $\mathrm{D}^{-}-\mathrm{lysine-}$ coated 35 mm culture dish (Becton Dickenson, Bedford, MA, USA) containing the HEPES-buffered solution. A grid of nylon threads glued to a U-shaped metal frame was used to hold the brain slice down during cell dissociation. After the VTA was visually identified, the vibrating stylus was placed in the appropriate region with a micromanipulator. The stylus was made of glass capillary tubing (1.5 mm o.d.) pulled to a fine tip, fire-polished (200 - $400 \mu \mathrm{m}$ in diameter) and mounted on the vibrating apparatus, which horizontally vibrated the stylus tip (excursions of $100-200 \mu \mathrm{m}$ at $20-25 \mathrm{~Hz}$ ). Once the cell dissociation procedure was completed (4 - $7 \mathrm{~min}$ ), the brain slice was removed from the culture dish, and the dissociated neurons settled and adhered to the bottom of the dish within $20 \mathrm{~min}$. 


\subsection{Nystatin-Perforated Patch Recording in Dissociated Neurons}

Electrophysiological measurements were made with an Axopatch-1B patch-clamp amplifier (Axon Instruments, Union City, CA, USA). Microelectrodes were fabricated on a P-97 puller (Sutter Instrument Company, Novato, CA, USA), from LE16 glass capillaries (Dagan, Minneapolis, MN, USA) and heat-polished on a microforge (Narishige, Tokyo, Japan). The tip resistances of the electrodes were 3 - $7 \mathrm{M} \Omega$ when filled with a pipette solution (in mM: $60 \mathrm{~K}$-acetate, $60 \mathrm{KCl}, 1 \mathrm{CaCl}_{2}, 2 \mathrm{MgCl}_{2}, 40 \mathrm{HEPES}$; $\mathrm{pH} 7.2$ adjusted with $\mathrm{KOH}$, final $\left[\mathrm{K}^{+}\right]_{\mathrm{i}}=131$ $\mathrm{mM}$; osmolality $290 \mathrm{mOsm}$ ). Nystatin-perforated patch recording was used to minimize the dialysis of intracellular contents and therefore prevent the rundown of $\mathrm{I}_{\mathrm{M}}$, as previously described [22]. Nystatin was dissolved in methanol at a concentration of $10 \mathrm{mg} / \mathrm{ml}$. This nystatin stock solution was diluted with the pipette solution to a final concentration of $100-200 \mu \mathrm{g} / \mathrm{ml}$ and the electrodes were backfilled with this solution. After the cell-attached configuration was attained, the access resistance was periodically monitored and capacitive transients were cancelled. When the access resistance had reached a steady level (15 - $30 \mathrm{M} \Omega)$, the recording was started. In case of the sudden change of the access resistance, the recording was stopped. Voltage-clamp recording was done in a HEPES-buffered solution (in mM: $145 \mathrm{NaCl}, 2.5 \mathrm{KCl}, 2 \mathrm{CaCl}_{2}, 1 \mathrm{MgCl}_{2}, 10 \mathrm{HEPES}$ and $11_{\mathrm{D}}$-glucose; $\mathrm{pH}$ adjusted to 7.4 with $\mathrm{NaOH}$; osmolarity $300 \mathrm{mOsm}$ ) constantly bubbled with $100 \% \mathrm{O}_{2}$. The liquid junction potential between the pipette solution and the HEPES-buffered solution was estimated to be $5 \mathrm{mV}$ [23] and the results have been corrected by this amount. Membrane currents and voltage were filtered at $1 \mathrm{kHz}$ by a $-3 \mathrm{~dB} 4$-pole filter and acquired at a sampling frequency of $10 \mathrm{kHz}$, which is higher than the Nyquist's critical sampling rate. Data acquisition was performed with a DigiData 1322A interface and pClamp software version 9.0 (Axon Instruments Inc., Union City, CA, USA). The dissociated VTA neurons were visualized under phase-contrast optics on an inverted microscope (Diaphot 300, Nikon, Tokyo, Japan). All experiments were performed at room temperature $\left(23^{\circ} \mathrm{C}-25^{\circ} \mathrm{C}\right)$.

\subsection{Drug Application for Dissociated Neurons}

Neurons were continuously bathed in the external solution and drugs were dissolved at final concentration in the same solution. Drug solutions were applied via a multiple channel manifold (MLF-4; ALA Scientific Instruments, Westbury, NY, USA). Each channel of the manifold was connected to a gravity-fed reservoir with tubing (860 $\mu$ m, i.d.). The output of the manifold was connected to an outflow tube (500 $\mu \mathrm{m}$, i.d.), the tip of which was placed within $200 \mu \mathrm{m}$ of the soma of the recorded neuron. Solutions flowed continuously through one manifold channel. Application of drug solutions was controlled by opening or closing valves connected to the reservoirs.

\subsection{Preparation of Brain Slices}

Following rapid removal of the brain, the tissue block containing the VTA was mounted in the Vibratome and submerged in the ice-cold cutting solution. Coronal sections ( $400 \mu \mathrm{m}$ thick) were cut and the slice was placed on a mesh platform in the recording chamber. The slice was totally submerged in the ACSF maintained at a flow rate of $2 \mathrm{ml} / \mathrm{min}$; the temperature in the recording chamber was kept at $35^{\circ} \mathrm{C}$. The ACSF was saturated with $95 \%$ $\mathrm{O}_{2}$ and $5 \% \mathrm{CO}_{2}(\mathrm{pH}=7.4)$. Equilibration time of at least one hour was allowed after placement of the brain slice in the recording chamber before electrodes were placed in the tissue. Recording electrodes were placed in the VTA under visual control. Only those neurons which were anatomically located within the VTA and which conformed to the electrophysiological criteria for dopaminergic neurons [24] were studied. These criteria include broad action potentials and regular spontaneous firing frequency at 0.5 - $5 \mathrm{~Hz}$.

\subsection{Extracellular Recording in Brain Slices}

Extracellular recording electrodes were fabricated from $1.5 \mathrm{~mm}$ diameter glass tubing and were filled with $0.9 \%$ $\mathrm{NaCl}$. Tip resistance of the microelectrodes ranged from 3 to $8 \mathrm{M} \Omega$. The Fintronics amplifier (Fintronics Inc., Orange, CT, USA) used in these recordings had a window discriminator, the output of which was fed to both a rectilinear pen recorder and a computer-based data acquisition system for on-line and off-line analysis of the data. The multiplexed output of the amplifier was displayed on an analog storage oscilloscope, for accurate adjustment of the window levels used to monitor single units. An IBM-PC-based data acquisition system was used to calculate, display and store the frequency of firing over 5 sec and 1 min intervals. 


\subsection{Drug Administration for Brain Slices}

Drugs were added to the ACSF by means of a calibrated infusion pump from stock solutions 100 to 1000 times the desired final concentrations. The addition of drug solutions to the ACSF was performed in such a way as to permit the drug solution to mix completely with the ACSF before this mixture reached the recording chamber. The use of a calibrated, variable speed infusion pump permits the accurate addition of several concentrations of drugs from the same stock solution. Final concentrations were calculated from the ACSF flow rate, pump infusion speed and the concentration of drug stock solution. The small volume chamber (about $300 \mu \mathrm{l}$ ) used in this study permitted the rapid application and washout of drug solutions. Typically drugs reached equilibrium in the tissue after 2 to 3 minutes of application.

\subsection{Drugs and Chemical Agents}

$\mathrm{BaCl}_{2}, \mathrm{CdCl}_{2}, \mathrm{CoCl}_{2}$, HEPES, $\mathrm{NiCl}_{2}$, nystatin and $\mathrm{ZnCl}_{2}$ were purchased from Sigma (Saint Louis, MO, USA). Papain was purchased from Worthington (Lakewood, NJ, USA).

\subsection{Data Analysis and Curve Fitting}

Action potentials were analyzed offline with pClamp 9.0 software (Axon Instruments Inc.). All average values are expressed as mean \pm standard error of the mean (SE). Graphing and curve fitting of data was performed with Origin 7 software (OriginLab Corp., Northampton, MA, USA). Concentration-response curves for zinc were constructed by plotting percent inhibition of $\mathrm{I}_{\mathrm{M}}$ as a function of drug concentration plotted on a log scale. Smooth curves were fit to these data with the Hill equation of the form [25]:

$$
y=y_{\max } x^{n} /\left(k^{n}+x^{n}\right)
$$

where $x$ is the concentration, $y$ is the percent inhibition and $y_{\max }$ is the maximal value of $y$ (at saturation); in the fitting procedure $y_{\max }$ was constrained not to exceed $100 \%$. The term $k$ is the $\mathrm{IC}_{50}$ (the concentration giving halfmaximal inhibition) and $n$ (Hill slope) is the power term related to the slope of the curve. To assess the changes in spontaneous firing with drugs, drug effect was quantitated as the mean change in firing rate (normalized as the percentage of control) for 60 sec-long interval during the peak of the drug response as previously described [26]. The formula for this normalization is:

$$
\begin{aligned}
& \text { Firing rate increase }(\%) \\
& =[(\text { firing rate with drug })-(\text { firing rate in control })] /(\text { firing rate in control }) \times 100
\end{aligned}
$$

Data from dissociated cells with action potential amplitudes less than $50 \mathrm{mV}$ were discarded. All average values are expressed as mean \pm standard error (SE). Statistical comparison to assess significant differences was done by one-way ANOVA as appropriate followed by a Bonferroni correction. When needed, the Student-Newman-Keuls post hoc test was used to test multiple comparisons. Correlation was evaluated by linear regression with $P<0.05$ being considered significant.

\section{Results}

\subsection{Zinc $\left(\mathrm{Zn}^{2+}\right)$ Inhibits M-Current $\left(\mathrm{I}_{\mathrm{M}}\right)$ in Ventral Tegmental Area Dopamine (DA VTA) Neurons}

After obtaining a stable perforated patch recording, DA VTA neurons were identified in current-clamp recording based on the electrophysiological characteristics by matching spontaneous firing frequency and action potential (AP) parameters, as described previously [22]. Then, $\mathrm{I}_{\mathrm{M}}$ was measured in the same DA VTA neuron in voltageclamp configuration.

$\mathrm{I}_{\mathrm{M}}$ was measured in the standard deactivation protocol [8] with 1 sec-long hyperpolarizing voltage step from a holding potential $\left(\mathrm{V}_{\mathrm{H}}\right)$ of $-25 \mathrm{mV}$ to $-40 \mathrm{mV}$. $\mathrm{I}_{\mathrm{M}}$ was measured as the inward relaxation current caused by deactivation of $\mathrm{I}_{M}$ during the voltage step (Figure 1(a)). Figure 1(a1) shows $\mathrm{I}_{M}$ before, during and after treatment with $100 \mu \mathrm{M} \mathrm{Zn}{ }^{2+}$ in a typical DA VTA neuron. $\mathrm{Zn}^{2+}$ reduced $\mathrm{I}_{\mathrm{M}}$ amplitude and also reduced the sustained outward current present at $-25 \mathrm{mV}$ as indicated by the inward shift in the baseline current. Just after the termination 


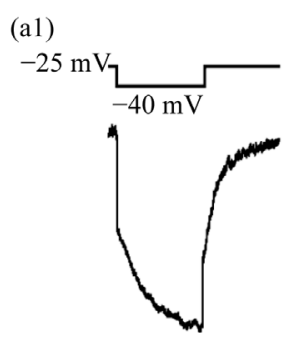

control

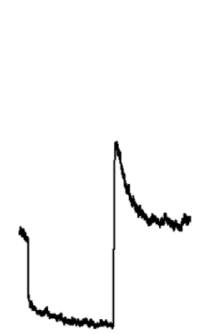

Zn $100 \mu \mathrm{M}$

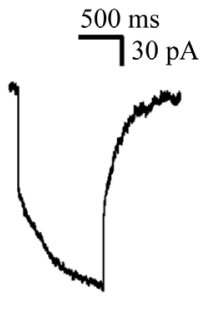

washout

(a2)

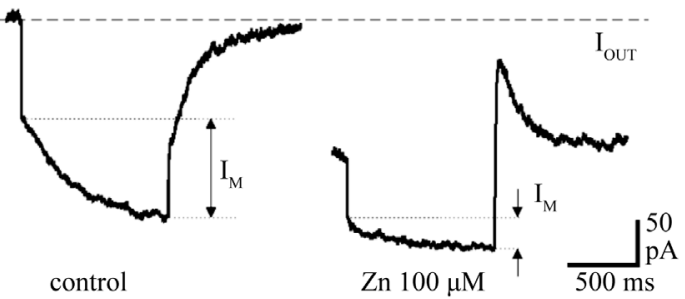

(b)

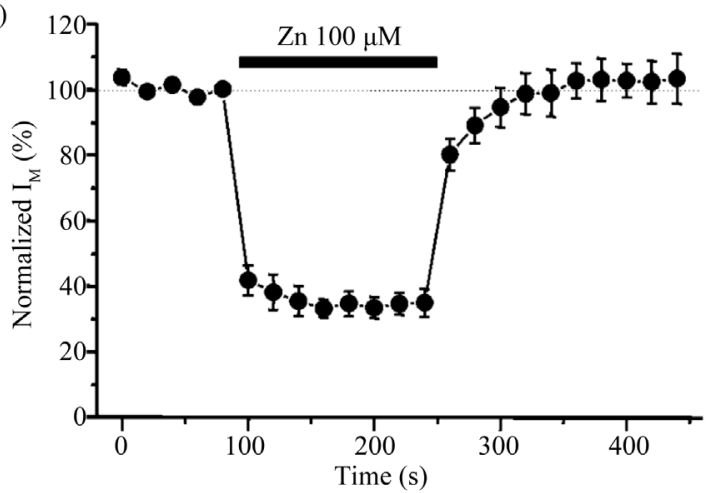

Figure 1. Zinc inhibition of $\mathrm{I}_{\mathrm{M}}$ in DA VTA neurons. $A_{1}$ : $\mathrm{I}_{\mathrm{M}}$ recorded before, during and after application of $100 \mu \mathrm{M}$ zinc $\left(\mathrm{Zn}^{2+}\right)$ in a DA VTA neuron. $\mathrm{I}_{\mathrm{M}}$ was measured in the standard deactivation protocol with 1 sec-long hyperpolarizing voltage step from a holding potential $\left(\mathrm{V}_{\mathrm{H}}\right)$ of $-25 \mathrm{mV}$ to $-40 \mathrm{mV}$. Each $\mathrm{I}_{\mathrm{M}}$ trace was obtained by averaging 5 current recordings from the neuron. $A_{2}$ : $\mathrm{I}_{\mathrm{M}}$ was measured as the inward relaxation current caused by deactivation of $I_{M}$ (arrows between dotted lines) during the voltage step; the difference between the instantaneous current at the beginning and the steady-state current at the end of the voltage step before (left) and after $\mathrm{Zn}^{2+}$ treatment (right) was measured. The dashed line represents sustained outward current $\left(\mathrm{I}_{\mathrm{OUT}}\right)$ at a $\mathrm{V}_{\mathrm{H}}$ of $-25 \mathrm{mV}$ before $\mathrm{Zn}^{2+}$ treatment. B: The average time course of $100 \mu \mathrm{M} \mathrm{Zn}^{2+}$ effect on $I_{M}$ from DA VTA neurons $(n=6)$. $I_{M}$ was measured with 1 sec-long hyperpolarizing voltage step from a $\mathrm{V}_{\mathrm{H}}$ of $-25 \mathrm{mV}$ to $-40 \mathrm{mV}$. This hyperpolarizing voltage step was given in every 20 sec. Each $I_{M}$ amplitude was normalized to the average $I_{M}$ amplitude obtained from the 5 events just before the application of $\mathrm{Zn}^{2+}$.

of the hyperpolarizing voltage step from $-25 \mathrm{mV}$ to $-40 \mathrm{mV}$, a transient outward current was recorded in the presence of $\mathrm{Zn}^{2+}$ (Figure 1(a1), middle panel). This current is likely to be transient A-type $\mathrm{K}^{+}$current $\left(\mathrm{I}_{\mathrm{A}}\right)$, because DA VTA neurons exhibit prominent $\mathrm{I}_{\mathrm{A}}$ [27] and $\mathrm{Zn}^{2+}$ shifts the voltage-dependency of steady-state $\mathrm{I}_{\mathrm{A}}$ inactivation to the depolarizing direction [28]. In the presence of zinc, $\mathrm{I}_{\mathrm{A}}$ can be activated at a membrane potential of $-40 \mathrm{mV}$. Figure 1(a2) shows the measurement of the inward relaxation current caused by deactivation of $\mathrm{I}_{\mathrm{M}}$ during the voltage step; the difference between the instantaneous current at the beginning $\left(\mathrm{I}_{\mathrm{in}}\right)$ and the steadystate current at the end of the voltage step $\left(\mathrm{I}_{\mathrm{ss}}\right)$. Figure $1(\mathrm{~b})$ shows the average time course of normalized $\mathrm{I}_{\mathrm{M}}$ amplitude before, during and after application of $100 \mu \mathrm{M} \mathrm{Zn}^{2+}$ in DA VTA neurons. $\mathrm{I}_{\mathrm{M}}$ recovered completely after 
the washout of $\mathrm{Zn}^{2+}$ in DA VTA neurons.

\subsection{Concentration-Dependent Inhibition of $\mathrm{IM}_{\mathrm{M}}$ by $\mathrm{Zn}^{2+}$}

Figure 2(a) shows that $\mathrm{Zn}^{2+}$ caused a concentration-dependent reduction of $\mathrm{I}_{\mathrm{M}}$ amplitude in a typical DA VTA neuron. $\mathrm{Zn}^{2+}$ also caused a concentration-dependent reduction of the baseline sustained outward current. The $300 \mu \mathrm{M}$ concentration appeared to produce a inhibitory effect near to or at the maximum, since it did not inhibit $\mathrm{I}_{\mathrm{M}}$ substantially more than the $100 \mu \mathrm{M}$ concentration. $\mathrm{Zn}^{2+}$ at $300 \mu \mathrm{M}$ did not produce complete inhibition of $\mathrm{I}_{\mathrm{M}}$. Figure 2(b) shows the pooled concentration-response curve which plots normalized $\mathrm{I}_{\mathrm{M}}$ amplitude versus log concentration of $\mathrm{Zn}^{2+}$ from DA VTA neurons. The Hill equation was used to fit a smooth curve to the mean data in Figure 2(b). The $\mathrm{IC}_{50}$ for $\mathrm{Zn}^{2+}$ was $5.8 \mu \mathrm{M}$ and the Hill slope was 0.8 .

\subsection{Zinc Inhibition of $I_{M}$ Is Not Voltage-Dependent}

We then examined whether zinc inhibition of $I_{M}$ was voltage-dependent. Figure 3(a) shows $I_{M}$ induced by a series of hyperpolarizing voltage steps before, during, and after treatment with $100 \mu \mathrm{M} \mathrm{Zn}^{2+}$. $\mathrm{Zn}^{2+}$ inhibited $\mathrm{I}_{\mathrm{M}}$ amplitude measured with all four hyperpolarizing voltage steps in 6 DA VTA neurons. $\mathrm{I}_{\mathrm{A}}$ activation can be seen after the offset of the larger voltage steps in control and washout, while $\mathrm{I}_{\mathrm{A}}$ is not prominent after the offset of the

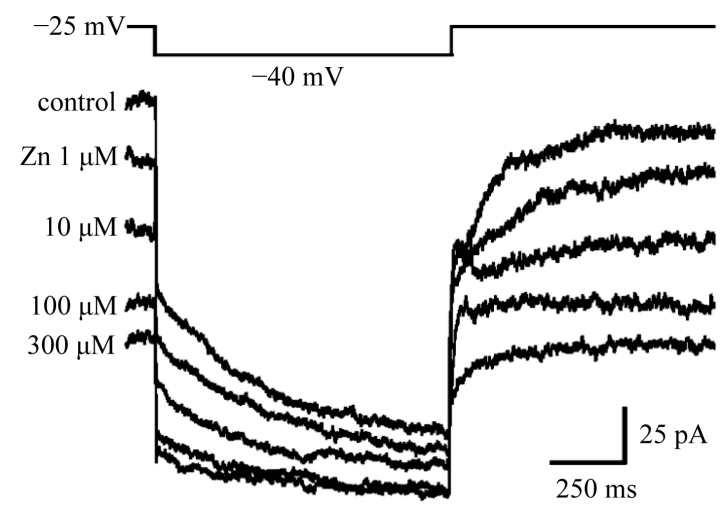

(a)

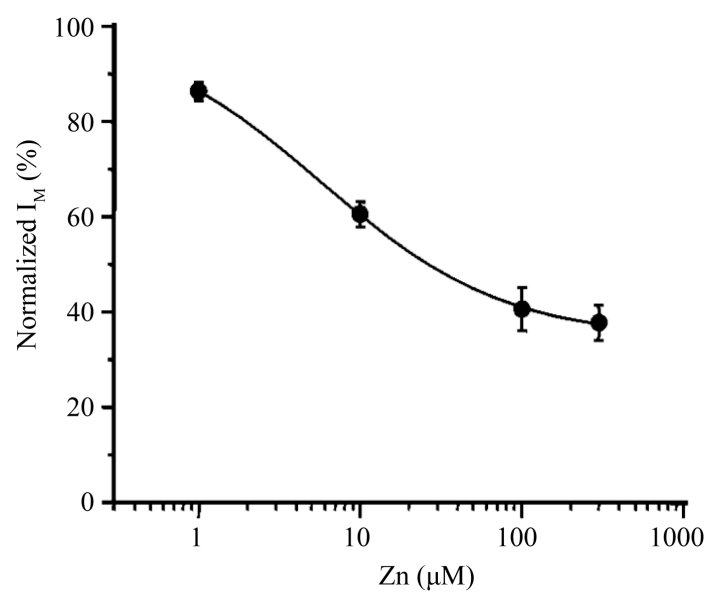

(b)

Figure 2. Concentration-dependent inhibition of $\mathrm{I}_{\mathrm{M}}$ by $\mathrm{Zn}^{2+}$ in DA VTA neurons. (a) Zinc inhibition of $I_{M}$ is concentration-dependent. $I_{M}$ traces are superimposed. The baseline outward current was shifted by $\mathrm{Zn}^{2+}$ (at a $\mathrm{V}_{\mathrm{H}}$ of $-25 \mathrm{mV}$ ). Each $\mathrm{I}_{\mathrm{M}}$ trace was obtained by averaging 5 current recordings at each $\mathrm{Zn}^{2+}$ concentration; (b) Concentration-response curve showing mean normalized $\mathrm{I}_{\mathrm{M}}$ amplitude as a function of $\log \mathrm{Zn}^{2+}$ concentration for DA VTA neurons $(n=5)$. The smooth curve was fitted with the Hill equation. 

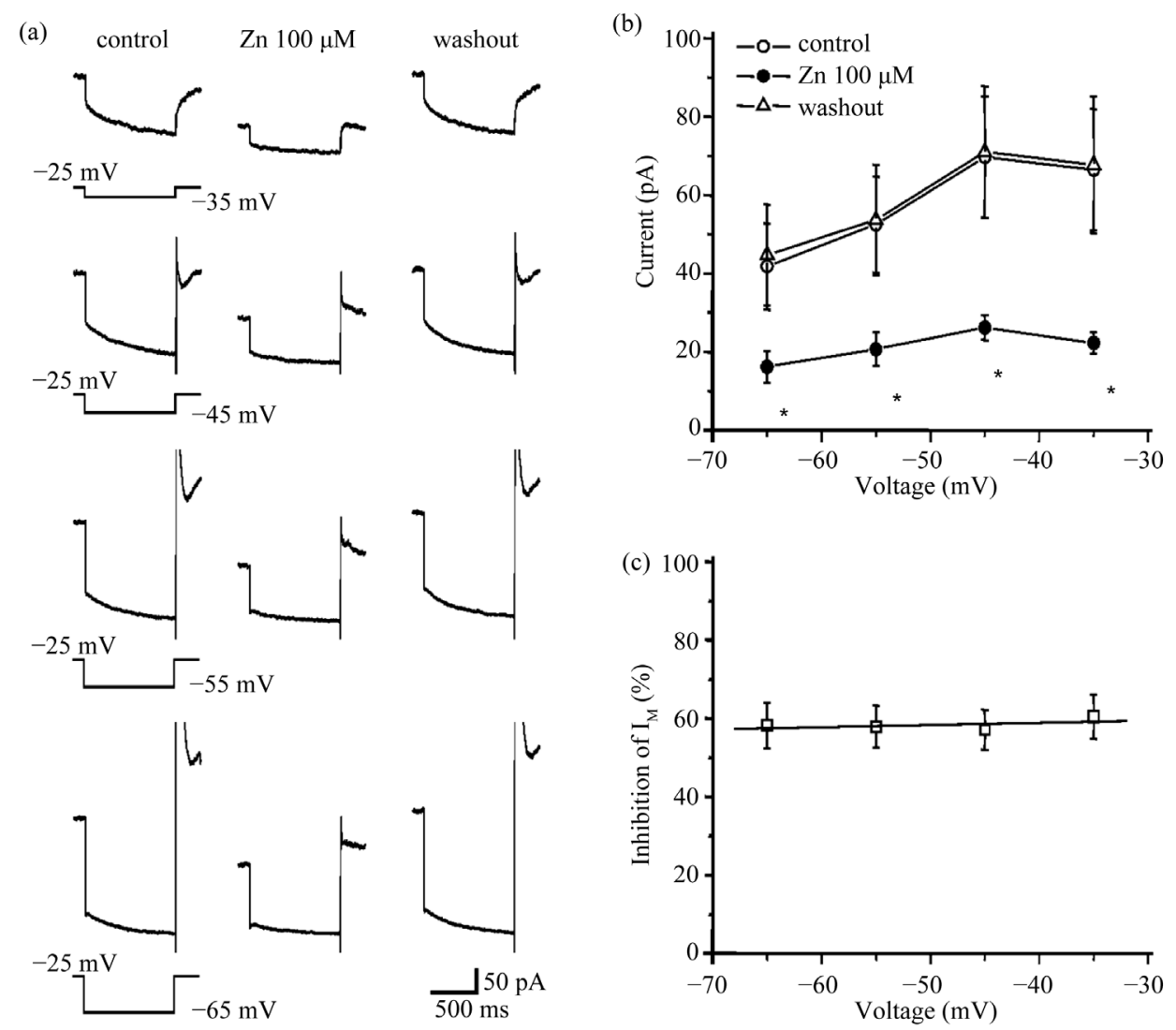

Figure 3. Zinc inhibition of $I_{M}$ is not voltage-dependent. (a) $I_{M}$ induced by four different hyperpo-

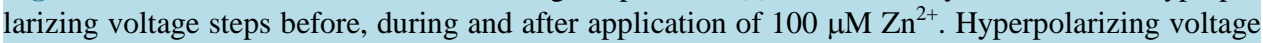
steps were given from a $V_{H}$ of $-25 \mathrm{mV}$ to $-65 \mathrm{mV}$ in $10 \mathrm{mV}$ increments. Each $\mathrm{I}_{\mathrm{M}}$ trace was obtained by averaging the currents from 6 DA VTA neurons; (b) Relationship between membrane

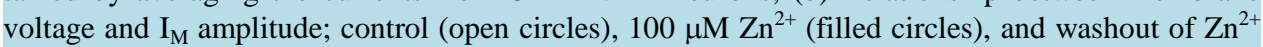
(open triangles) $(\mathrm{n}=6)$; (c) Relationship between voltage and average $\% \mathrm{I}_{\mathrm{M}}$ inhibition by $100 \mu \mathrm{M}$ $\mathrm{Zn}^{2+}(\mathrm{n}=6) .{ }^{*} \mathrm{P}<0.05$.

larger voltage steps in the presence of $\mathrm{Zn}^{2+}$ (Figure 3(a)). This is likely due to a $\mathrm{Zn}^{2+}$-induced shift in the voltage-dependency of steady-state $\mathrm{I}_{\mathrm{A}}$ activation in the depolarizing direction [29]. Figure 3(b) shows the relationship between membrane voltage and $\mathrm{I}_{\mathrm{M}}$ amplitude before, during, and after treatment with $100 \mu \mathrm{M} \mathrm{Zn}^{2+}$ for DA VTA neurons. $\mathrm{Zn}^{2+}$ inhibited $\mathrm{I}_{\mathrm{M}}$ amplitude at any voltage examined. There was no correlation between membrane voltage and the $\% \mathrm{I}_{\mathrm{M}}$ inhibition by $\mathrm{Zn}^{2+}$ (Figure 3(c)).

\section{4. $\mathrm{Zn}^{2+}$ Increases the Spontaneous Firing Frequency of DA VTA Neurons}

The effect of $\mathrm{Zn}^{2+}$ on the spontaneous firing frequency of DA VTA neurons was measured with extracellular single-unit recording of these neurons in brain slices. The percentage increase in firing frequency produced by $\mathrm{Zn}^{2+}$ was calculated. Figure 4 shows the concentration-response relationship between $\mathrm{Zn}^{2+}$ and the firing rate change by $\mathrm{Zn}^{2+}$ from DA VTA neurons. Average $\mathrm{Zn}^{2+}$-induced increase in firing frequency was $17.3 \% \pm 10.6 \%$ with $10 \mu \mathrm{M} \mathrm{Zn}^{2+}$ and $49.5 \% \pm 7.6 \%$ with $50 \mu \mathrm{M} \mathrm{Zn}^{2+}(\mathrm{n}=5)$.

\subsection{IM Inhibition by $\mathrm{Ba}^{2+}, \mathrm{Co}^{2+}, \mathrm{Ni}^{2+}$ and $\mathrm{Cd}^{2+}$}

Finally, we examined whether divalent cations other than $\mathrm{Zn}^{2+}$ modulated $\mathrm{I}_{\mathrm{M}}$ (Figure 5). $\mathrm{Ba}^{2+}, \mathrm{Co}^{2+}, \mathrm{Ni}^{2+}$ and $\mathrm{Cd}^{2+}$ at a concentration of $100 \mu \mathrm{M}$ all reduced $\mathrm{I}_{\mathrm{M}}$ amplitude and induced an inward shift of the baseline outward current in DA VTA neurons, however their potencies for $\mathrm{I}_{\mathrm{M}}$ inhibition were different (Figures 5(a)-(d)). Just after the termination of the hyperpolarizing voltage step from $-25 \mathrm{mV}$ to $-40 \mathrm{mV}, \mathrm{I}_{\mathrm{A}}$ was recorded in the pres- 


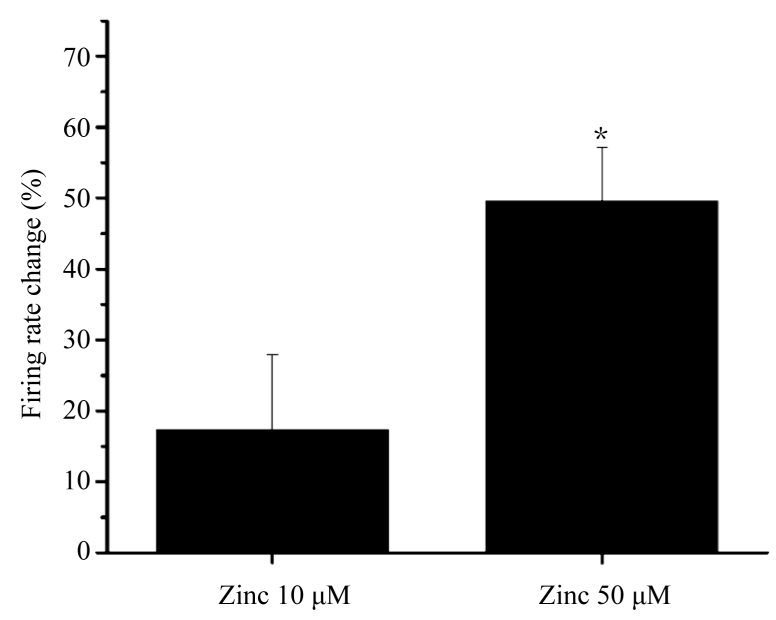

Figure 4. Effect of $\mathrm{Zn}^{2+}$ on the firing frequency of DA VTA neurons in brain slices. Pooled concentration-response relationship for $\mathrm{Zn}^{2+}(10$ and $50 \mu \mathrm{M})$ effects on spontaneous firing rate measured in DA VTA neurons from adult rats (3 months old $)(n=5) .{ }^{*} P<0.05$.

ence of $\mathrm{Cd}^{2+}$ (Figure 5(d), middle panel), because $\mathrm{Cd}^{2+}$, like $\mathrm{Zn}^{2+}$, shifts the voltage-dependency of steady-state $\mathrm{I}_{\mathrm{A}}$ inactivation in the depolarizing direction [28]. Figure 6(a) shows the average time course of normalized $\mathrm{I}_{\mathrm{M}}$ amplitude before, during and after application of $100 \mu \mathrm{M}$ divalent cations in DA VTA neurons. $\mathrm{I}_{\mathrm{M}}$ of DA VTA neurons were inhibited by $100 \mu \mathrm{M}$ extracellular divalent cations in increasing order of potency: $\mathrm{Ba}^{2+}<\mathrm{Co}^{2+}<\mathrm{Ni}^{2+}$ $<\mathrm{Cd}^{2+}<\mathrm{Zn}^{2+}$. Average maximal inhibition of $\mathrm{I}_{\mathrm{M}}$ was $15.6 \% \pm 3.0 \%$ with $\mathrm{Ba}^{2+}(\mathrm{n}=7), 24.9 \% \pm 2.2 \%$ with $\mathrm{Co}^{2+}$ $(\mathrm{n}=6), 39.5 \% \pm 4.2 \%$ with $\mathrm{Ni}^{2+}(\mathrm{n}=7), 59.0 \% \pm 3.5 \%$ with $\mathrm{Cd}^{2+}(\mathrm{n}=6)$, and $66.8 \% \pm 2.8 \%$ with $\mathrm{Zn}^{2+}(\mathrm{n}=6)$.

\section{Discussion}

Extracellular $\mathrm{Zn}^{2+}$ inhibited $\mathrm{I}_{\mathrm{M}}$ in a concentration-dependent manner with $\mathrm{IC}_{50}$ value of $5.8 \mu \mathrm{M}$ in DA VTA neurons; the $\mathrm{IC}_{50}$ value is smaller than that reported for rodent neuroblastoma $\mathrm{x}$ glioma hybrid cells $(11 \mu \mathrm{M})$ [19] or bullfrog sympathetic neurons $(300 \mu \mathrm{M})$ [20]. We estimate the maximal inhibition of $\mathrm{I}_{\mathrm{M}}$ by zinc to be about $62 \%$ with $38 \%$ of this current remaining unblocked by $\mathrm{Zn}^{2+}$ in DA VTA neurons. Since our previous study has confirmed the inward relaxation current obtained by the same voltage protocol in the present study to be $\mathrm{I}_{\mathrm{M}}$ in DA VTA neurons [22], $\mathrm{I}_{\mathrm{M}}$ of these neurons can be classified into $\mathrm{Zn}^{2+}$-sensitive and $\mathrm{Zn}^{2+}$-insensitive components. Previous immunohistochemical studies have shown that KCNQ2 and KCNQ4 channel proteins are present in VTA neurons [11] [12]. Hansen et al. (2006) have reported that the KCNQ4 channel subunit is the main component of $\mathrm{I}_{\mathrm{M}}$ in DA VTA neurons, and found weak immunoreactivity of the KCNQ2 channel subunit and lack of KCNQ3 channel immunoreactivity in VTA neurons [13]. Since the KCNQ2 and the KCNQ4 channel subunits cannot be coassembled as a functional heteromeric channel in vitro [30], the KCNQ2 and the KCNQ4 channels may contribute to $\mathrm{I}_{\mathrm{M}}$ independently, as homomers, in a DA VTA neuron. KCNQ4 channels may underlie the $\mathrm{Zn}^{2+}$-sensitive component of $\mathrm{I}_{\mathrm{M}}$ and KCNQ2 channels may underlie the remaining $\mathrm{Zn}^{2+}$-insensitive component of $\mathrm{I}_{\mathrm{M}}$. It is unlikely that the KCNQ5 channel component is a significant contributor to $\mathrm{I}_{\mathrm{M}}$ in DA VTA neurons, since KCNQ5 channels are potentiated by $\mathrm{Zn}^{2+}$ in a concentration-dependent manner [31].

In DA VTA neurons, zinc inhibition of $I_{M}$ was not voltage-dependent and the Hill slope was near $1(0.8)$ for the concentration-dependent zinc inhibition of $\mathrm{I}_{\mathrm{M}}$. These observations suggest a single $\mathrm{Zn}^{2+}$ site of action and one that is different from the voltage-sensitive region of the M-channels. Furthermore, it seems likely that the site of action of zinc in DA VAT neurons is not the M-channel pore, since the mechanism for voltage-dependent $\mathrm{I}_{\mathrm{M}}$ inhibition with divalent cation $\left(\mathrm{Ba}^{2+}\right)$ has been reported to be KCNQ channel pore blocking [32]. The voltage-dependency for the action of divalent cations on KCNQ/M-current differ among experimental preparations. In neuroblastoma $\mathrm{x}$ glioma hybrid cells [19] and the rod photoreceptor of tiger salamander [33], $\mathrm{I}_{\mathrm{M}}$ inhibition by $\mathrm{Ba}^{2+}$ or $\mathrm{Cd}^{2+}$ shows voltage-dependency. Expressed KCNQ2/KCNQ3 heteromeric channels are inhibited by $\mathrm{Ba}^{2+}$ in a voltage-independent manner [34]. 
(a)

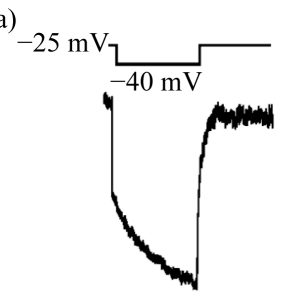

control

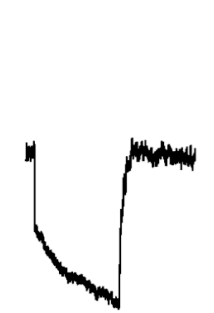

Ba $100 \mu \mathrm{M}$

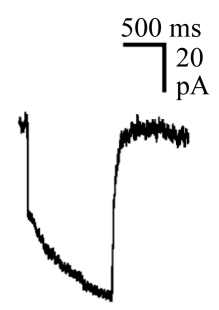

washout

(b)

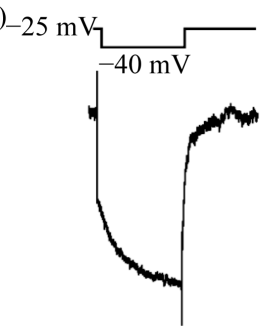

control

(c)

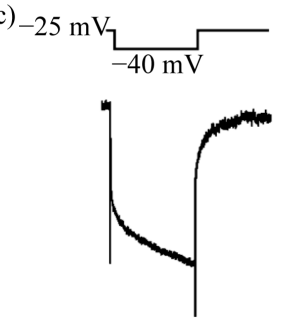

control

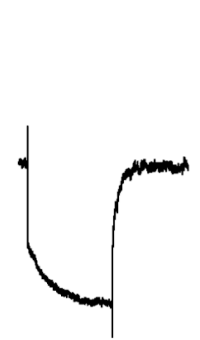

Co $100 \mu \mathrm{M}$

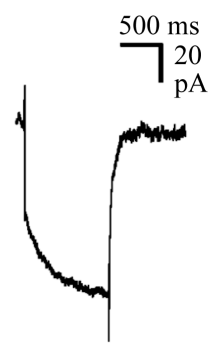

washout

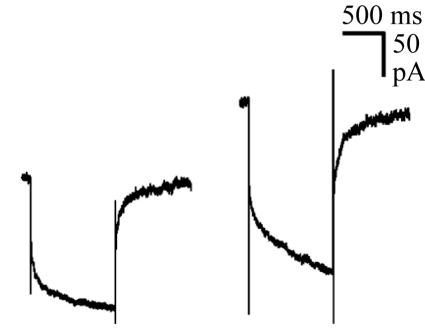

$\mathrm{Ni} 100 \mu \mathrm{M}$

washout (d)

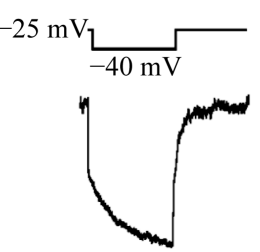

control

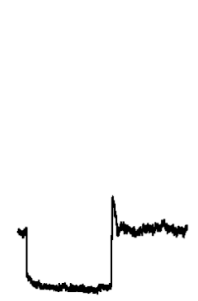

Cd $100 \mu \mathrm{M}$

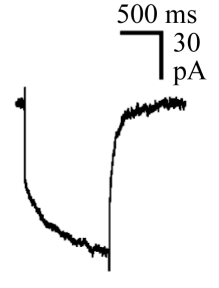

washout

Figure 5 . $\mathrm{I}_{\mathrm{M}}$ inhibition by divalent cations in DA VTA neurons. (a) $\mathrm{I}_{\mathrm{M}}$ recorded before, during and after application of $100 \mu \mathrm{M}$ barium $\left(\mathrm{Ba}^{2+}\right)$ in a DA VTA neuron. $\mathrm{I}_{\mathrm{M}}$ was measured in the standard deactivation protocol with 1 sec-long hyperpolarizing voltage step from a $V_{H}$ of $-25 \mathrm{mV}$ to $-40 \mathrm{mV}$. Each $\mathrm{I}_{\mathrm{M}}$ was obtained by averaging 5 currents for the neuron; Effects of other divalent cations on $\mathrm{I}_{\mathrm{M}}$ in DA VTA neurons were recorded by the same protocol and illustrated in the same method as described above: $100 \mu \mathrm{M}$ cobalt $\left(\mathrm{Co}^{2+}\right)$ (b); $100 \mu \mathrm{M}$ nickel $\left(\mathrm{Ni}^{2+}\right)$ (c); and $100 \mu \mathrm{M}$ cadmium $\left(\mathrm{Cd}^{2+}\right)(\mathrm{d})$.

Our extracellular recording study revealed that a relatively low concentration of $\mathrm{Zn}^{2+}(50 \mu \mathrm{M})$ significantly increased the spontaneous firing frequency of DA VTA neurons. Taken together with the present voltage-clamp analysis, zinc inhibited $\mathrm{I}_{\mathrm{M}}$ and subsequently increased the excitability of DA VTA neurons, leading to increase in firing frequency of these neurons (Figure 7). Consistent with our present study, it has been reported that $\mathrm{Zn}^{2+}$ $(10-100 \mu \mathrm{M})$ increases the firing frequency during evoked spike trains in midbrain DA neurons of the SN in a 

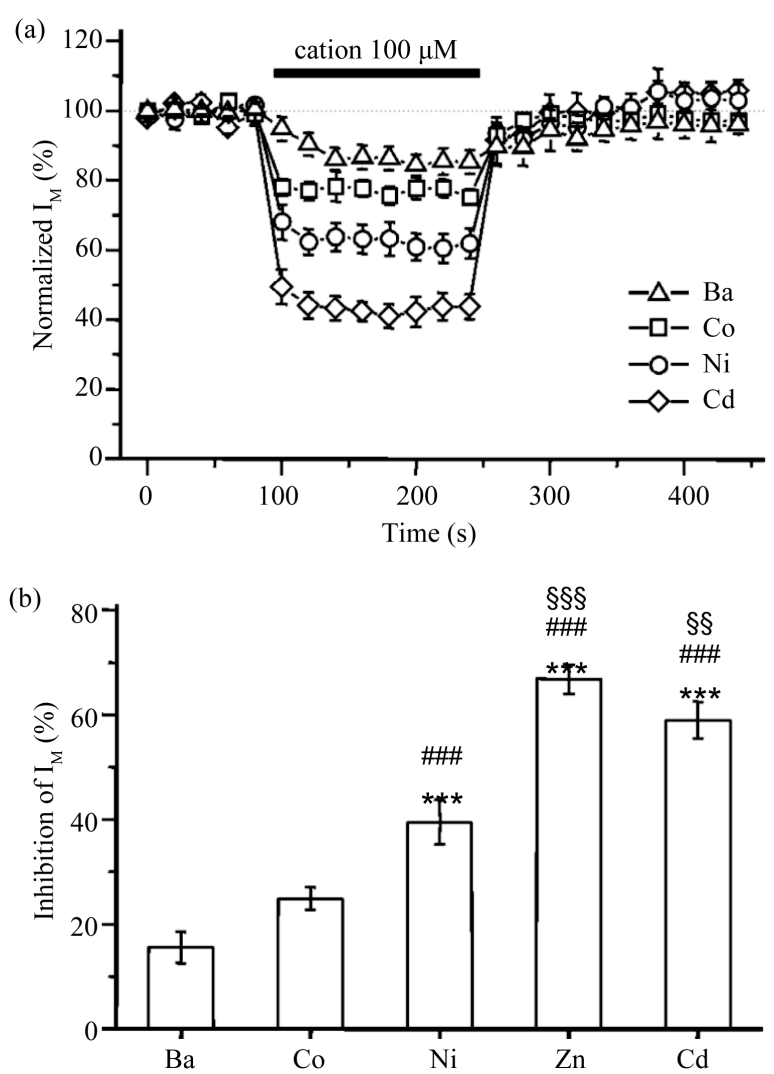

Figure 6. Different potencies of divalent cations for $I_{M}$ inhibition. (a) The average time course of $100 \mu \mathrm{M}$ cation effect on $\mathrm{I}_{\mathrm{M}}$ in DA VTA neurons: $\mathrm{Ba}^{2+}$ (open triangles, $\mathrm{n}=7$ ), $\mathrm{Co}^{2+}$ (open squares, $\mathrm{n}=6$ ), $\mathrm{Ni}^{2+}$ (open circles, $\mathrm{n}=7$ ) and $\mathrm{Cd}^{2+}$ (open diamonds, $\mathrm{n}=6$ ). $\mathrm{I}_{\mathrm{M}}$ was measured with 1 sec-long hyperpolarizing voltage step from a $V_{H}$ of -25 $\mathrm{mV}$ to $-40 \mathrm{mV}$. This hyperpolarizing voltage step was given in every 20 sec. All $I_{M}$ amplitude was normalized to the average $I_{M}$ amplitude obtained from the 5 events just before the application of $\mathrm{Ba}^{2+}, \mathrm{Co}^{2+}$, $\mathrm{Ni}^{2+}$ and $\mathrm{Cd}^{2+}$; (b) The mean maximal inhibition of $\mathrm{I}_{\mathrm{M}}$ by $100 \mu \mathrm{M}$ $\mathrm{Ba}^{2+}, \mathrm{Co}^{2+}, \mathrm{Ni}^{2+}, \mathrm{Cd}^{2+}$ and $\mathrm{Zn}^{2+}$. ${ }^{* * *} P<0.001$ to $\mathrm{Ba}^{2+} ;{ }^{\# \#} \mathrm{P}<0.001$ to $\mathrm{Co}^{2+} ;{ }^{\S \S} \mathrm{P}<0.01 ;{ }^{\S \S \S} \mathrm{P}<0.001$ to $\mathrm{Ni}^{2+}$.

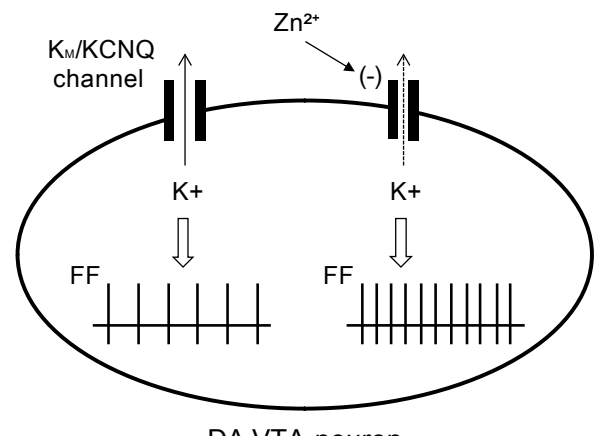

DA VTA neuron

Figure 7. Schematic illustration for the role of zinc in DA VTA neurons. In the control status, $\mathrm{K}_{\mathrm{M}} / \mathrm{KCNQ}$ channels open and outflow of $\mathrm{K}^{+}$ions from the cytoplasm hyperpolarizes membrane potentials, leading to inhibitory effect on DA VTA neurons. Zinc inhibits $\mathrm{K}_{\mathrm{M}} / \mathrm{KCNQ}$ channel opening and the subsequent decrease in the outflow of $\mathrm{K}^{+}$ions from the cytoplasm depolarizes membrane potentials, leading to excitation of DA VTA neurons with increase in FF. $\mathrm{K}_{\mathrm{M}}$, M-type $\mathrm{K}^{+}$channel; FF, firing frequency. 
concentration-dependent manner [21]. Several types of voltage-dependent ion currents contribute to the spontaneous activity of midbrain DA neurons. A high voltage-activated (HVA) $\mathrm{Ca}^{2+}$ current $\left(\mathrm{I}_{\mathrm{Ca}}\right.$ ) underlies the spontaneous oscillatory potential [35]. A low voltage-activated (LVA) transient $\mathrm{I}_{\mathrm{Ca}}$ is tightly coupled to a small conductance $\mathrm{Ca}^{2+}$-activated $\mathrm{K}^{+}$(SK) current which underlies the middle component of the after hyperpolarization [36]. A transient A-type $\mathrm{K}^{+}$current $\left(\mathrm{I}_{\mathrm{A}}\right)$ is critical for the regulation of inter-action potential trajectory by generating a time- and voltage-dependent repolarization delay [26] [37]. $\mathrm{I}_{\mathrm{M}}$ underlies the fast and slow components without affecting the middle component of AHP and prolongs inter-action potential intervals [22]. Many studies have reported that $\mathrm{Zn}^{2+}$ modulates all the types of ion currents described above. $\mathrm{Zn}^{2+}$ inhibits HVA $\mathrm{I}_{\mathrm{Ca}}$ with the $\mathrm{IC}_{50}$ value of $21 \mu \mathrm{M}$ and slows current activation [38]. $\mathrm{Zn}^{2+}$ inhibits LVA $\mathrm{I}_{\mathrm{Ca}}$ with the $\mathrm{IC}_{50}$ value from 11 to 55 $\mu \mathrm{M}$ [39] [40]. $\mathrm{Zn}^{2+}(10-1000 \mu \mathrm{M})$ shifts both steady-state activation and inactivation of $\mathrm{I}_{\mathrm{A}}$ to a depolarizing direction and slows current activation [27] [28] [41]. Thus, the $\mathrm{Zn}^{2+}$-induced excitation of midbrain DA neurons is likely to be the sum of zinc effects on HVA $\mathrm{I}_{\mathrm{Ca}}$, LVA $\mathrm{I}_{\mathrm{Ca}}, \mathrm{I}_{\mathrm{A}}$ and $\mathrm{I}_{\mathrm{M}}$. Since $\mathrm{I}_{\mathrm{M}}$ is more sensitive to $\mathrm{Zn}^{2+}\left(\mathrm{IC}_{50}=\right.$ $5.8 \mu \mathrm{M}$ ) than HVA $\mathrm{I}_{\mathrm{Ca}}$, LVA $\mathrm{I}_{\mathrm{Ca}}$ or $\mathrm{I}_{\mathrm{A}}$ and $\mathrm{Zn}^{2+}$ inhibition of $\mathrm{I}_{\mathrm{M}}$ was not voltage-dependent, $\mathrm{Zn}^{2+}$ can inhibit $\mathrm{I}_{\mathrm{M}}$ potently at any membrane potential during the spontaneous activity of DA VTA neurons and increase the excitability of these neurons as shown in the present study.

$\mathrm{I}_{\mathrm{M}}$ of DA VTA neurons were inhibited by $100 \mu \mathrm{M}$ extracellular divalent cations with the following of order of potency: $\mathrm{Zn}^{2+}>\mathrm{Cd}^{2+}>\mathrm{Ni}^{2+}>\mathrm{Co}^{2+}>\mathrm{Ba}^{2+}$. Similarly to the results with $\mathrm{Zn}^{2+}$, the onset of $\mathrm{I}_{\mathrm{M}}$ inhibition by $\mathrm{Ba}^{2+}$, $\mathrm{Cd}^{2+}, \mathrm{Co}^{2+}$ or $\mathrm{Ni}^{2+}$ was fast and $\mathrm{I}_{\mathrm{M}}$ recovered completely after the washout of these divalent cations. In neuroblastoma x glioma hybrid cells, $\mathrm{Cd}^{2+}, \mathrm{Ni}^{2+}$ and $\mathrm{Zn}^{2+}$ exhibit a similar order of potency for the inhibition of $\mathrm{I}_{\mathrm{M}}$ but $\mathrm{Ba}^{2+}$ is twice as potent as $\mathrm{Co}^{2+}[19]$. In the rod photoreceptor of tiger salamander, $\mathrm{I}_{\mathrm{M}}$ is inhibited by $\mathrm{Ba}^{2+}$ with the $\mathrm{IC}_{50}$ value of $7.6 \mathrm{mM}$ without apparent sensitivity to $5 \mathrm{mM} \mathrm{Co}^{2+}$ and $\mathrm{Zn}^{2+}$ [32]. Again, the specific KCNQ subunits, and their combination in functional channels, in each tissue may dictate the sensitivity to inhibition by these divalent cations.

Considering the fact that the concentration of $\mathrm{Zn}^{2+}$ is relatively high in the brain, we suggest that $\mathrm{Zn}^{2+}$ exerts physiologically significant regulation of neuronal excitability through an action on $\mathrm{I}_{\mathrm{M}}$. It has been shown that $\mathrm{Zn}^{2+}$ can be co-released with glutamate from presynaptic terminals, and the concentration of $\mathrm{Zn}^{2+}$ in the synapse has been estimated to be between 10 and $100 \mu \mathrm{M}$ [42] [43]. Our results indicate that the concentration of $\mathrm{Zn}^{2+}$ that is achieved during synaptic transmission could be expected to have effects on $\mathrm{I}_{\mathrm{M}}$ in addition to directly affecting glutamate neurotransmission. Therefore, inhibition of $\mathrm{I}_{\mathrm{M}}$ may be a critical aspect of the neuromodulatory action of $\mathrm{Zn}^{2+}$.

\section{Acknowledgements}

This work was supported by National Institute on Alcohol Abuse and Alcoholism Grant AA05846 (to S.B.A.). This study was partly supported by Grants-in-Aid for Scientific Research (C) (Nos. 22500685 and 25350166 to S.K.) from the Japan Society for the Promotion of Science (JSPS) and the Mishima Kaiun Memorial Foundation, Japan (to S.K.). This study was also supported by funds (No. 106006 to S.K.) from the General Research Institute of Fukuoka University.

\section{Competing Interests}

The authors have declared that no competing interests exist.

\section{References}

[1] Oades, R.D. and Halliday, G.M. (1987) Ventral Tegmental (A10) System: Neurobiology. 1. Anatomy and Connectivity. Brain Research, 434, 117-165. http://dx.doi.org/10.1016/0165-0173(87)90011-7

[2] Di Chiara, G. and Imperato, A. (1988) Drugs Abused by Humans Preferentially Increase Synaptic Dopamine Concentrations in the Mesolimbic System of Freely Moving Rats. Proceedings of the National Academy of Sciences of the USA, 85, 5274-5278. http://dx.doi.org/10.1073/pnas.85.14.5274

[3] Weiss, F., Lorang, M.T., Bloom, F.E. and Koob, G.F. (1993) Oral Alcohol Self-Administration Stimulates Dopamine Release in the Rat Nucleus Accumbens: Genetic and Motivational Determinants. Journal of Pharmacology and Experimental Therapeutics 267, 250-258.

[4] Wise, R.A. (2002) Brain Reward Circuitry: Insights from Unsensed Incentives. Neuron, 36, 229-240. http://dx.doi.org/10.1016/S0896-6273(02)00965-0 
[5] Corrigall, W.A., Coen, K.M. and Adamson, K.L. (1994) Self-Administered Nicotine Activates the Mesolimbic Dopamine System through the Ventral Tegmental Area. Brain Research, 653, 278-284.

http://dx.doi.org/10.1016/0006-8993(94)90401-4

[6] Pfeffer, A.O. and Samson, H.H. (1988) Haloperidol and Apomorphine Effects on Ethanol Reinforcement in Free Feeding Rats. Pharmacology Biochemistry and Behavior, 29, 343-350. http://dx.doi.org/10.1016/0091-3057(88)90167-0

[7] Aiken, S.P., Lampe, B.J., Murphy, P.A. and Brown, B.S. (1995) Reduction of Spike Frequency Adaptation and Blockade of M-Current in Rat CA1 Pyramidal Neurones by Linopirdine (DuP 996), a Neurotransmitter Release Enhancer. British Journal of Pharmacology, 115, 1163-1168. http://dx.doi.org/10.1111/j.1476-5381.1995.tb15019.x

[8] Brown, D.A. and Adams, P.R. (1980) Muscarinic Suppression of a Novel Voltage-Sensitive $\mathrm{K}^{+}$Current in a Vertebrate Neurone. Nature, 283, 673-676. http://dx.doi.org/10.1038/283673a0

[9] Wang, H.S., Pan, Z., Shi, W., Brown, B.S., Wymore, R.S., Cohen, I.S., Dixon, J.E. and McKinnon, D. (1998) KCNQ2 and KCNQ3 Potassium Channel Subunits: Molecular Correlates of the M-Channel. Science, 282, 1890-1893. http://dx.doi.org/10.1126/science.282.5395.1890

[10] Robbins, J. (2001) KCNQ Potassium Channels: Physiology, Pathophysiology, and Pharmacology. Pharmacology \& Therapeutics, 90, 1-9. http://dx.doi.org/10.1016/S0163-7258(01)00116-4

[11] Cooper, E.C., Harrington, E., Jan, Y.N. and Jan, L.Y. (2001) M Channel KCNQ2 Subunits Are Localized to Key Sites for Control of Neuronal Network Oscillations and Synchronization in Mouse Brain. Journal of Neuroscience, 21, 9529-9540.

[12] Kharkovets, T., Hardelin, J.P., Safieddine, S., Schweizer, M., El-Amraoui, A., Petit, C. and Jentsch, T.J. (2000) KCNQ4, a K ${ }^{+}$ Channel Mutated in a Form of Dominant Deafness, Is Expressed in the Inner Ear and the Central Auditory Pathway. Proceedings of the National Academy of Sciences of the United States of America, 97, 4333-4338. http://dx.doi.org/10.1073/pnas.97.8.4333

[13] Hansen, H.H., Ebbesen, C., Mathiesen, C., Weikop, P., Ronn, L.C., Waroux, O., Scuvee-Moreau, J., Seutin, V. and Mikkelsen, J.D. (2006) The KCNQ Channel Opener Retigabine Inhibits the Activity of Mesencephalic Dopaminergic Systems of the Rat. Journal of Pharmacology and Experimental Therapeutics, 318, 1006-1019. http://dx.doi.org/10.1124/jpet.106.106757

[14] Zecca, L., Pietra, R., Goj, C., Mecacci, C., Radice, D. and Sabbioni, E. (1994) Iron and Other Metals in Neuromelanin, Substantia Nigra, and Putamen of Human Brain. Journal of Neurochemistry, 62, 1097-1101. http://dx.doi.org/10.1046/j.1471-4159.1994.62031097.x

[15] Romans, A.Y., Graichen, M.E., Lochmuller, C.H. and Henkens, R.W. (1987) Kinetics and Mechanism of Dissociation of Zinc Ion from Carbonic Anhydrase. Bioinorganic Chemistry, 9, 217-229. http://dx.doi.org/10.1016/S0006-3061(78)80007-6

[16] Perez-Clausell, J. and Danscher, G. (1985) Intravesicular Localization of Zinc in Rat Telencephalic Boutons. A Histochemical Study. Brain Research, 337, 91-98. http://dx.doi.org/10.1016/0006-8993(85)91612-9

[17] Assaf, S.Y. and Chung, S.H. (1984) Release of Endogenous $\mathrm{Zn}^{2+}$ from Brain Tissue during Activity. Nature, 308, 734736. http://dx.doi.org/10.1038/308734a0

[18] Harrison, N.L. and Gibbons, S.J. (1994) $\mathrm{Zn}^{2+}$ : An Endogenous Modulator of Ligand- and Voltage-Gated Ion Channels. Neuropharmacology, 33, 935-952. http://dx.doi.org/10.1016/0028-3908(94)90152-X

[19] Robbins, J., Trouslard, J., Marsh, S.J. and Brown, D.A. (1992) Kinetic and Pharmacological Properties of the M-Current in Rodent Neuroblastoma x Glioma Hybrid Cells. Journal of Physiology, 451, 159-185.

[20] Hirasawa, T., Kudo, Y. and Tokimasa, T. (1998) Actions of Zinc on Rapidly Inactivating A-Type and Non-Inactivating M-Type Potassium Currents in Bullfrog Sympathetic Neurons. Neuroscience Letters, 255, 5-8. http://dx.doi.org/10.1016/S0304-3940(98)00683-1

[21] Chung, J.M., Chang, S.Y., Kim, Y.I. and Shin, H.C. (2000) Zinc Increases the Excitability of Dopaminergic Neurons in Rat Substantia Nigra. Neuroscience Letters, 286, 183-186. http://dx.doi.org/10.1016/S0304-3940(00)01120-4

[22] Koyama, S. and Appel, S.B. (2006) Characterization of M-Current in Ventral Tegmental Area Dopamine Neurons. Journal of Neurophysiology, 96, 535-543. http://dx.doi.org/10.1152/jn.00574.2005

[23] Neher, E. (1992) Correction for Liquid Junction Potential in Patch Clamp Experiments. Methods in Enzymology, 207, 123-131. http://dx.doi.org/10.1016/0076-6879(92)07008-C

[24] Mueller, A.L. and Brodie, M.S. (1989) Intracellular Recording from Putative Dopamine-Containing Neurons in the Ventral Tegmental Area of Tsai in a Brain Slice Preparation. Journal of Neuroscience Methods, 28, 15-22. http://dx.doi.org/10.1016/0165-0270(89)90005-8

[25] Zot, H.G., Hasbun, J.E. and Van Minh, N. (2012) Second-Chance Signal Transduction Explains Cooperative Flagellar 
Switching. PLoS ONE, 7, e41098. http://dx.doi.org/10.1371/journal.pone.0041098

[26] Brodie, M.S., Shefner, S.A. and Dunwiddie, T.V. (1990) Ethanol Increases the Firing Rate of Dopamine Neurons of the Rat Ventral Tegmental Area in Vitro. Brain Research, 508, 65-69. http://dx.doi.org/10.1016/0006-8993(90)91118-Z

[27] Koyama, S. and Appel, S.B. (2006) A-Type $\mathrm{K}^{+}$Current of Dopamine and GABA Neurons in the Ventral Tegmental Area. Journal of Neurophysiology, 96, 544-554. http://dx.doi.org/10.1152/jn.01318.2005

[28] Kuo, C.C. and Chen, F.P. (1999) $\mathrm{Zn}^{2+}$ Modulation of Neuronal Transient $\mathrm{K}^{+}$Current: Fast and Selective Binding to the Deactivated Channels. Biophysical Journal, 77, 2552-2562. http://dx.doi.org/10.1016/S0006-3495(99)77090-6

[29] Harrison, N.L., Radke, H.K., Talukder, G. and Ffrench-Mullen, J.M. (1993) Zinc Modulates Transient Outward Current Gating in Hippocampal Neurons. Receptors \&Channels, 1, 153-163.

[30] Kubisch, C., Schroeder, B.C., Friedrich, T., Lütjohann, B., El-Amraoui, A., Marlin, S., Petit, C. and Jentsch, T.J. (1999) KCNQ4, a Novel Potassium Channel Expressed in Sensory Outer Hair Cells, Is Mutated in Dominant Deafness. Cell, 96, 437-446. http://dx.doi.org/10.1016/S0092-8674(00)80556-5

[31] Jensen, H.S., Callo, K., Jespersen, T., Jensen, B.S. and Olesen, S.P. (2005) The KCNQ5 Potassium Channel from Mouse: A Broadly Expressed M-Current Like Potassium Channel Modulated by Zinc, pH and Volume Changes. Molecular Brain Research, 139, 52-62. http://dx.doi.org/10.1016/j.molbrainres.2005.05.007

[32] Gibor, G., Yakubovich, D., Peretz, A. and Attali, B. (2004) External Barium Affects the Gating of KCNQ1 Potassium Channels and Produces a Pore Block via Two Discrete Sites. Journal of General Physiology, 124, 83-102. http://dx.doi.org/10.1085/jgp.200409068

[33] Wollmuth, L.P. (1994) Mechanism of $\mathrm{Ba}^{2+}$ Block of M-Like K Channels of Rod Photoreceptors of Tiger Salamanders. Journal of General Physiology, 103, 45-66. http://dx.doi.org/10.1085/jgp.103.1.45

[34] Prole, D.L. and Marrion, N.V. (2004) Ionic Permeation and Conduction Properties of Neuronal KCNQ2/KCNQ3 Potassium Channels. Biophysical Journal, 86, 1454-1469. http://dx.doi.org/10.1016/S0006-3495(04)74214-9

[35] Kang, Y. and Kitai, S.T. (1993) Calcium Spike Underlying Rhythmic Firing in Dopaminergic Neurons of the Rat Substantia Nigra. Neuroscience Research, 18, 195-207. http://dx.doi.org/10.1016/0168-0102(93)90055-U

[36] Wolfart, J. and Roeper, J. (2002) Selective Coupling of T-Type Calcium Channels to SK Potassium Channels Prevents Intrinsic Bursting in Dopaminergic Midbrain Neurons. Journal of Neuroscience, 22, 3404-3413.

[37] Liss, B., Franz, O., Sewing, S., Bruns, R., Neuhoff, H. and Roeper, J. (2001) Tuning Pacemaker Frequency of Individual Dopaminergic Neurons by Kv4.3L and KChip3.1 Transcription. EMBO Journal, 20, 5715-5724. http://dx.doi.org/10.1093/emboj/20.20.5715

[38] Magistretti, J., Castelli, L., Taglietti, V. and Tanzi, F. (2003) Dual Effect of $\mathrm{Zn}^{2+}$ on Multiple Types of Voltage-Dependent $\mathrm{Ca}^{2+}$ Currents in Rat Palaeocortical Neurons. Neuroscience, 117, 249-264. http://dx.doi.org/10.1016/S0306-4522(02)00865-5

[39] Noh, J.H. and Chung, J.M. (2003) Zinc Reduces Low-Threshold $\mathrm{Ca}^{2+}$ Currents of Rat Thalamic Relay Neurons. Neuroscience Research, 47, 261-265. http://dx.doi.org/10.1016/S0168-0102(03)00198-6

[40] Todorovic, S.M. and Lingle, C.J. (1998) Pharmacological Properties of T-Type Ca ${ }^{2+}$ Current in Adult Rat Sensory Neurons: Effects of Anticonvulsant and Anesthetic Agents. Journal of Neurophysiology, 79, 240-252.

[41] Huang, R.C., Peng, Y.W. and Yau, K.W. (1993) Zinc Modulation of a Transient Potassium Current and Histochemical Localization of the Metal in Neurons of the Suprachiasmatic Nucleus. Proceedings of the National Academy of Sciences of the United States of America, 90, 11806-11810. http://dx.doi.org/10.1073/pnas.90.24.11806

[42] Vogt, K., Mellor, J., Tong, G. and Nicoll, R. (2000) The Actions of Synaptically Released Zinc at Hippocampal Mossy Fiber Synapses. Neuron, 26, 187-196. http://dx.doi.org/10.1016/S0896-6273(00)81149-6

[43] Li, Y., Hough, C.J., Suh, S.W., Sarvey, J.M. and Frederickson, C.J. (2001) Rapid Translocation of $\mathrm{Zn}^{2+}$ from Presynaptic Terminals into Postsynaptic Hippocampal Neurons after Physiological Stimulation. Journal of Neurophysiology, 86, 2597-2604. 
Scientific Research Publishing (SCIRP) is one of the largest Open Access journal publishers. It is currently publishing more than 200 open access, online, peer-reviewed journals covering a wide range of academic disciplines. SCIRP serves the worldwide academic communities and contributes to the progress and application of science with its publication.

Other selected journals from SCIRP are listed as below. Submit your manuscript to us via either submit@scirp.org or Online Submission Portal.
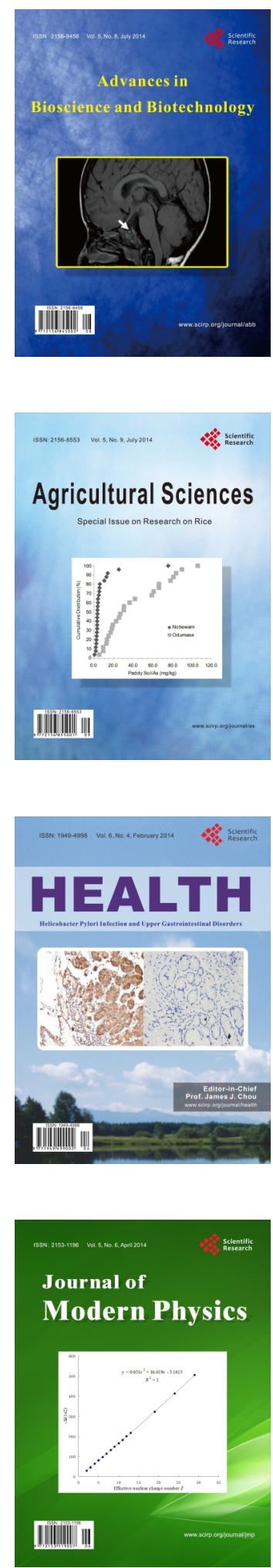
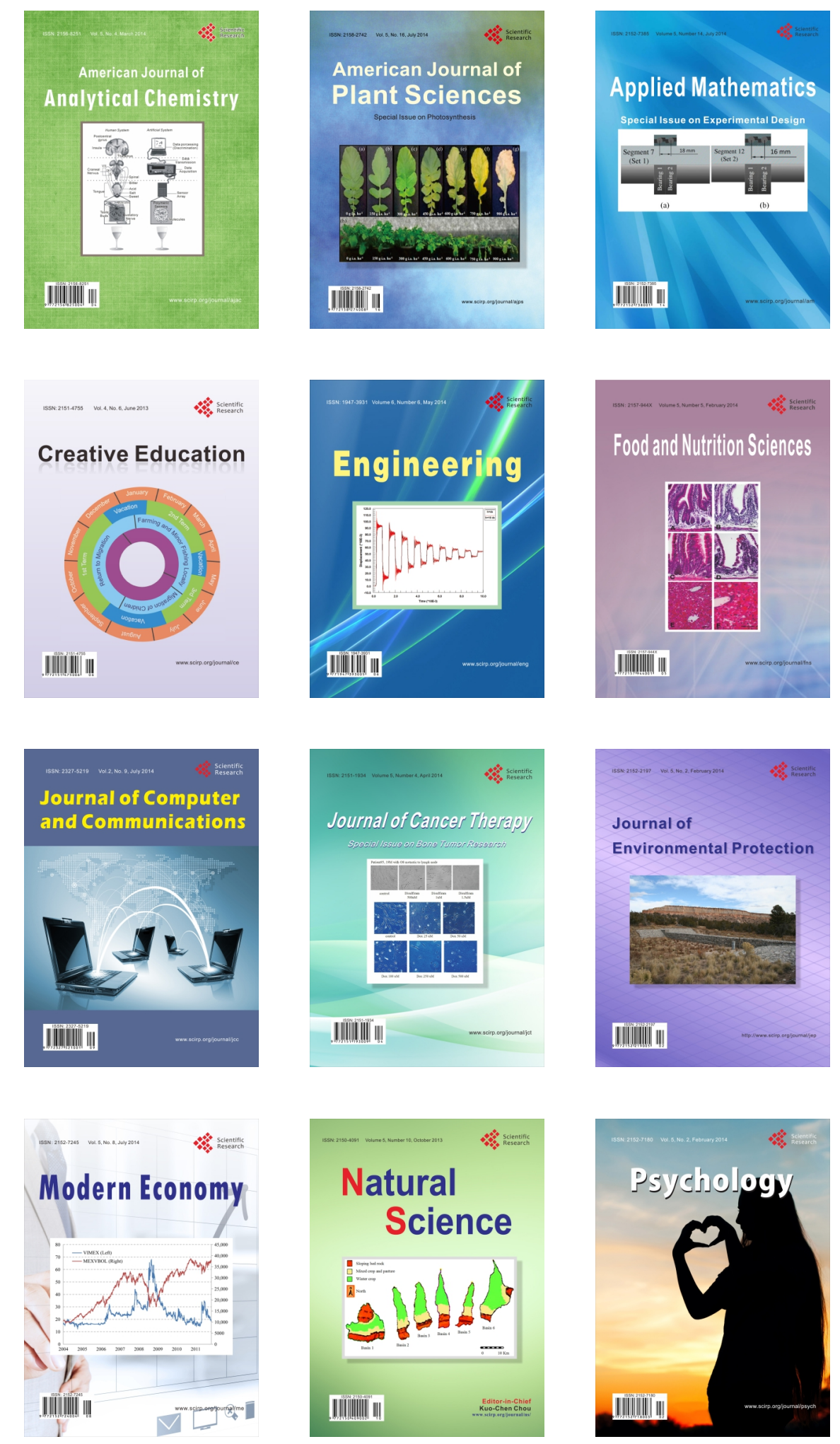